\title{
MJN EFFECTS OF DIABETIC CAMP ON SELF EFFICACY AMONG MIDDLE- AGED AND ELDERLY PEOPLE WITH TYPE 2 DIABETES MELLITUS
}

\author{
Junaidy Suparman Rustam*, Aulia Putri \\ Yarsi Health Science College, Bukittinggi, West Sumatra, Indonesia \\ *Corresponding Author's Email: junaidy.rustam25@gmail.com
}

\begin{abstract}
Introduction: The benefits of Diabetic Camp as known can be applied to promote knowledge and selfmanagement among diabetes people. Nevertheless, empirical data of its effect on diabetes self-efficacy are still limited, especially on middle aged and elderly people with type 2 Diabetes Mellitus. Objectives: The purpose of this intervention study was to investigate the change of self-efficacy among middle-aged and elderly people living with type $2 \mathrm{DM}$ after attending camp. Methods: A quasi-experimental study was used. Eighty-four participants were recruited form two public health center in Bukittnggi City West Sumatra Indonesia were randomly assigned into either the experimental group $(n=42)$ or control group $(n=42)$ by matching technique based on gender, age, and duration of illness. The experimental group participated in diabetic camp for two days continuing with weekly follow up for over 1 month while those in the control group participated in routine activities. Outcome was measured by using Self-efficacy Questionnaire for Diabetes at the first day before receiving the intervention as pretest data, and on the four weeks after the intervention was completed as the posttest data. The reliability of the Self-efficacy Questionnaire for Diabetes with Cronbach's alpha coefficient was 0.81 . Descriptive and inferential statistics were performed to analyze the data. Results: Mean of self-efficacy score in the experimental group after receiving the intervention was significantly higher than those in the control group $(t=4.27 ; p<0.05)$. The mean of self-efficacy score after receiving the intervention in the experimental group was increased significantly from before receiving the intervention $(t=8.15 ; p<0.05)$. Conclusions: The results showed that Diabetic camp was effective in promoting self-efficacy of middle-aged and elderly people with type $2 \mathrm{DM}$. Thus, this diabetes care program can be recommended for practice.
\end{abstract}

Keywords: Self-Efficacy; Diabetic Camp; Type 2 Diabetes Mellitus; Middle-aged; Elderly

\section{INTRODUCTION}

Diabetes mellitus (DM) is a chronic disease that cannot be cured but can be controlled so that complications do not occur (Federation, 2017). Selfcontrol has an important role in controlling diabetes. One of the factors to consider is self-efficacy which encourages motivation to directly promote health behavior through self-confidence. So, self-efficacy is very important in changing the process of self-care behavior or self-management (Mohebi et al., 2013).

Self-efficacy in DM patients is related with the description of individual behavior regarding diet management, exercise / exercise, and diabetes behavior patterns (Osborn et al. 2010). Low self-efficacy in DM patients can have an impact on the failure of the DM treatment program which needs to be handled carefully in order to avoid complications that arise due to treatment programs that are not running as they should (Funnell et al., 2008). One of the interventions that can be applied is Diabetic Camp.

The American Diabetes Association (2012) recommends Diabetic Camp as a group method that can be used as a more effective intervention because of the combination of a process of changing knowledge, behavior, psychological and social changes that can continuously improve the self-efficacy and skills of DM sufferers in care management, both self or diabetic care. The Diabetic camp program combines educational programs with interactive learning in a nonclinical setting (Fegan-Bohm et al., 2016). The concept of 
implementing Diabetic camp is more fun for DM sufferers so that it can stimulate motivation, desire to learn and socialization activities between participants that occur during the camp (Park et al., 2017).

Previous studies have shown that diabetic camps can have a positive impact on DM sufferers, especially in children (Semiz et al., 2000), there is only limited literature published on the application of diabetic camps in adults. Therefore, the Diabetic Camp program, can be provided especially in the adult population with type 2 DM to increase self-efficacy in undergoing DM treatment throughout their life.

\section{Objectives}

The purpose of this study was to determine the effect of Diabetic Camp on Self-efficacy among middle-aged and elderly people with type $2 \mathrm{DM}$ patients.

\section{METHODOLOGY}

\section{Study Design}

The study used a quasi-experimental with pretestposttest design. The experimental group received Diabetic camp that was provided for two days, the control group received routine activity.

\section{Setting and Sample}

The participants were recruited from two Public Health Center (PHC) in Bukittinggi City, West Sumatra, Indonesia. The inclusion criteria were (1) age 30-70 years (2) Duration of illness with type $2 \mathrm{DM} \leq 10$ years (3) stayed with family; (4) can write and read in Indonesian; and (5) do not have hearing or cognitive problem. Exclusion criteria were; (1) type 2 DM patients with complications, and (2) having history of mental health problem.

Sample size was calculated based on effect size from the previous research (Winsett et al., 2010) about the diabetes camp program for adolescents with type 1 diabetes, the effect size is 60 , so with a research power of 0.80 and a degree of confidence $95 \%$ the number of samples in this study was obtained 35 people per group. In order to prevent type II error, the sample size was added 20\% for each group (Polit \& Beck, 2017). Hence, this study used 42 people per group with a total sample of 84 people.

Then, matching technique was performed based on gender (male and female), age ( \pm 5 years), and duration of illness ( \pm 1 years). The first patients who met the inclusion criteria were assigned by using a lottery to each the experimental group or control group. If the first patient was assigned to the control group, then the next patient who matched the inclusion criteria based on the characteristic of the first patient was assigned to the experimental group. This technique was continued until the researcher obtained the total number of the sample in each group.

\section{Description of the interventions}

The intervention in this study was provided by implementing the Diabetic Camp by providing an educational program in a group-based educational program and a social ability program for type $2 \mathrm{DM}$ patients. This intervention consisted of four session. The interventions were provided by the first researcher for two days in the experimental group and the continued with telephone coaching once a week for the next three weeks.

\section{Measurements}

The instrument that has been used in this study includes 1) Characteristics questionnaire 2) Selfefficacy for diabetes questionnaire, 3) Blood sugar examination. The validity of the intervention was measured through 3 experts in DM.

Self-efficacy for diabetes questionnaire from the Self-management Resource Center (SMRC) was used to measure self-efficacy in this study (Lorig et al., 2009). This tool was translated by the researchers to Indonesian language by using Back translation Technique (Brislin, 1978). The content validity test of the Self-efficacy for diabetes questionnaire showed the scale content validity index (S-CVI) was 0.92 and the Cronbach alpha coefficient for the reliability test was 0.81 .

\section{Data Collection}

Demographic data were collected by the first researcher from Characteristics questionnaire. A research assistant collected pre-test and post-test data with Self Efficacy for Diabetes Questionnaire. The pretest data were collected prior to the intervention at base line on day 1 and the post-test data were done after the intervention was completed on week 4 .

\section{Analysis}

Descriptive statistics were used to analyze and describe demographic characteristics of the participants. Since the data met the assumption (normality and homogeneity) conditions, paired $t$-test was performed to detect any within-groups effect between before and after the intervention and independent $t$-test was used to 
analyze any significant differences between two groups.

\section{RESULTS}

\section{Demographic Data of Participants}

Table.1 presents demographic data of the participants including age, gender, marital status, educational level, occupation, and duration of illness. Most of the demographic data between two groups showed that there were not statistically difference, except on marital status.

Tabel 1: Demographic Data of the Participants $(N=84)$

\begin{tabular}{|c|c|c|c|c|c|c|}
\hline \multirow[t]{2}{*}{ Characteristics } & \multicolumn{2}{|c|}{$\begin{array}{c}\text { Experimental } \\
\text { group } \\
(\mathrm{n}=\mathbf{4 2})\end{array}$} & \multicolumn{2}{|c|}{$\begin{array}{l}\text { Control group } \\
(n=42)\end{array}$} & \multirow[t]{2}{*}{$\begin{array}{l}\text { t/Chi- } \\
\text { Square }\end{array}$} & \multirow[t]{2}{*}{$p$} \\
\hline & $\mathrm{N}$ & $\%$ & $\mathrm{~N}$ & $\%$ & & \\
\hline Age (Min-Max = 43-69) & $\begin{array}{c}M= \\
56.86\end{array}$ & $\begin{array}{c}S D= \\
7.41\end{array}$ & $\begin{array}{c}M= \\
58.10\end{array}$ & $\begin{aligned} & S D \\
= & 6.03\end{aligned}$ & 0.84 & 0.40 \\
\hline $\begin{array}{l}\text { Gender } \\
\text { Male } \\
\text { Female }\end{array}$ & $\begin{array}{c}9 \\
33\end{array}$ & $\begin{array}{l}21.4 \\
78.6\end{array}$ & $\begin{array}{c}9 \\
33\end{array}$ & $\begin{array}{l}21.4 \\
78.6\end{array}$ & $0.00^{\mathrm{a}}$ & 1.00 \\
\hline $\begin{array}{l}\text { Marital status } \\
\text { Married } \\
\text { Widow/Divorced }\end{array}$ & $\begin{array}{l}28 \\
14\end{array}$ & $\begin{array}{l}66.6 \\
33.3\end{array}$ & $\begin{array}{c}36 \\
6\end{array}$ & $\begin{array}{l}85.7 \\
14.3\end{array}$ & $4.29^{\mathrm{b}}$ & 0.03 \\
\hline $\begin{array}{l}\text { Educational level } \\
\text { Elementary school } \\
\text { Junior school } \\
\text { Senior high school } \\
\text { Diploma/Bachelor }\end{array}$ & $\begin{array}{c}9 \\
5 \\
20 \\
8\end{array}$ & $\begin{array}{l}21.4 \\
11.9 \\
47.6 \\
19.0\end{array}$ & $\begin{array}{c}10 \\
5 \\
21 \\
6\end{array}$ & $\begin{array}{l}23.8 \\
11.9 \\
50.0 \\
14.3\end{array}$ & $2.16^{\mathrm{b}}$ & 0.71 \\
\hline $\begin{array}{l}\text { Occupation } \\
\text { Employee } \\
\text { Non-Employee } \\
\text { Farmer } \\
\text { Retired/Housewives }\end{array}$ & $\begin{array}{c}2 \\
7 \\
4 \\
29\end{array}$ & $\begin{array}{c}4.8 \\
17.5 \\
9.5 \\
69.0\end{array}$ & $\begin{array}{c}8 \\
6 \\
2 \\
26\end{array}$ & $\begin{array}{c}19.1 \\
14.3 \\
4.8 \\
61.9\end{array}$ & $5.78^{\mathrm{b}}$ & 0.22 \\
\hline $\begin{array}{c}\text { Duration of illness } \\
<5 \text { years } \\
>5 \text { years }\end{array}$ & $\begin{array}{l}32 \\
10\end{array}$ & $\begin{array}{l}76.2 \\
23.8\end{array}$ & $\begin{array}{l}32 \\
10\end{array}$ & $\begin{array}{l}76.2 \\
23.8\end{array}$ & $0.00^{\mathrm{a}}$ & 1.00 \\
\hline
\end{tabular}

\section{The Effect of Diabetic Camp on Self-efficacy}

The comparison of the mean of self-efficacy scores before and after the Diabetic Camp were presented in Table 2. The result showed that the mean scores of selfefficacies of the participants in the experimental group were significantly higher after following Diabetic camp then before the intervention $(t=12.38 ; p<0.05)$. In the control group, self-efficacy score of the participants following routine activity increased significantly $(t=5.34$; $p<0.05)$. However, the mean of self-efficacy scores was significantly higher on the participants in the experimental group $(\mathrm{M}=67.82 ; \mathrm{SD}=8.65)$ than those in the control group $(\mathrm{M}=54.29 ; \mathrm{SD}=5.94)(t=6.70 ; p<0.05)$.

Table 2: The Comparison of the Mean of Self-efficacy Scores Before and After the Diabetic Camp $(N=84)$

\begin{tabular}{|l|c|c|c|c|c|c|}
\hline \multirow{2}{*}{ Groups } & \multicolumn{2}{|c|}{ Pre-test } & \multicolumn{2}{|c|}{ Post-test } & \multirow{2}{*}{-test } & \multirow{2}{*}{$P$} \\
\cline { 2 - 6 } & $M$ & $S D$ & $M$ & $S D$ & & \\
\hline Experimental group & 49.82 & 6.55 & 67.82 & 8.65 & 12.38 & 0.00 \\
\hline Control group & 49.61 & 5.33 & 54.29 & 5.94 & 5.34 & 0.00 \\
\hline
\end{tabular}

\section{DISCUSSION}

Result of this study found that the mean self-efficacy score of the participants in the experimental and the control group significantly increased from the baseline, indicating increased self-efficacy scores. However, comparing these self-efficacy scores between two groups, it showed that the self-efficacy score of the participants in the experimental group were significantly higher after following Diabetic camp than those the participants in the control group who received routine activities $(t=6.70 ; p<0.05)$. These findings reflect that Diabetic camp was significantly effective in promoting self-efficacy on type $2 \mathrm{DM}$ patients.

Consistently, numerous studies have applied Diabetic camp for type 2 DM population, and it has positive effects in the variety of setting. Yet, related literature on the effects of diabetes camps are still limited, especially in adult population with DM type 2 . For example, a study by Park was conducted to examine the effect of Diabetic camp on self-management of middle-aged and elderly people with DM. Study results showed self-management increased significantly after following Diabetic camp. Hunt et al., (2012) declared that there was a significant relationship among the selfefficacy and self-behavior as determining factors to promote effective self-management of type 2 DM patients. Based on these findings, it can be concluded diabetic camp contributes to the improvement of selfmanagement of type 2 DM patients by increasing of selfefficacy.

The ultimate goal of Diabetic camp is to enhance patients' self-management and it can be demonstrated by the increasing self-efficacy in the experimental group following the interventions in this study. This study also revealed that there was a statistically significant difference on the mean score of self-efficacy between pretest and post-test in the control group. The improvement of self-efficacy score in the participants in the control group can be related with attandance of the participants in some routine diabetic care activity from the Public Health Center such as Diabetes excercise. Chester et al., (2018) mentioned that the routine diabetes care activities can promote self-efficacy among type $2 \mathrm{DM}$. However, this routine activity still needs to be designed appropriately in caring patients with type $2 \mathrm{DM}$ (Karagüzel et al., 2005).

\section{CONCLUSION}

According to the findings of this study, it is concluded that Diabetic camp increased patient's self- 
efficacy among type 2 Diabetes Melitus patients. This study also has effectively integrated telecoaching method in monitoring the intervention.

\section{Implication for Clinical Practice}

- Diabetic Camp was a holistic intervention and easy to provide in a brief session to increase selfefficacy among type $2 \mathrm{DM}$ patients.

- The Diabetic camp can be applied to fulfill social support among type $2 \mathrm{DM}$ patients.

- The Diabetic camp also may be associated with self management of type $2 \mathrm{DM}$ patients.

\section{Conflict of Interests}

The authors declare that they have no conflict of interest.

\section{ACKNOWLEDGEMENTS}

This study was supported and funded by the Indonesia Ministry of Research and Technology/National Research and Innovation Agency. Authors acknowledge to nurses and practicioners of two Public health center in Bukittinggi, West Sumatra Indonesia, including patients and their family for participations.

\section{REFRENCES}

American Diabetes Association (2012). Diabetes management at camps for children with diabetes. Diabetes Care, 35(Supplement 1), pp S72-S75.

Brislin, R.W. (1978). Contributions of Cross-Cultural Orientation Programmes and Power Analysis to Translation/Interpretation. In D. Gerver \& H.W. Sinaiko (Eds.), Language interpretation and communication. London: Plenum Press.

Chester, B.H., Stanley, W.G. \& Thangiah, G. (2018). The Efficacy of Registered Dietitian Interventions in Type 2 Diabetes Management in a Family Practice Clinic in North Alabama. Diabetes.

Federation, International Diabetes (2017). IDF Diabetes Atlas Eighth Edition 2017.

Fegan-Bohm, K., Weissberg-Benchell, J., DeSalvo, D., Gunn, S. \& Hilliard, M, 2016. Camp for youth with type 1 diabetes. Current diabetes reports, 16(8), p 68.

Funnell, M.M., Brown, T.L., Childs, B.P., Haas, L.B., Hosey, G.M., Jensen, B., Maryniuk, M., Peyrot, M., Piette, J.D., Reader, D. \& Siminerio, L.M. (2008). National standards for diabetes self-management education. Diabetes Care, 31(Supplement 1), pp S97-S104.

Hunt, C.W., Wilder, B., Steele, M.M., Grant, J.S., Pryor, E.R. \& Moneyham, L. (2012). Relationships among selfefficacy, social support, social problem solving, and self-management in a rural sample living with type 2 diabetes mellitus. Research and Theory for Nursing Practice, 26(2), pp 126-141.

Karagüzel, G., Bircan, I., Erişir, S. \& Bundak, R. (2005). Metabolic control and educational status in children with type 1 diabetes: effects of a summer camp and intensive insulin treatment. Acta Diabetologica, 42(4), pp.156-161.

Lorig, K., Ritter, P.L., Villa, F.J. \& Armas, J. (2009). Community-based peer-led diabetes self-management. The Diabetes Educator, 35(4), pp 641-651.

Mohebi, S., Azadbakht, L., Feizi, A., Sharifirad, G. \& Kargar, M. (2013). Review the key role of self-efficacy in diabetes care. Journal of Education and Health Promotion, 2:36.

Osborn, C.Y., Cavanaugh, K., Wallston, K.A. \& Rothman, R.L. (2010). Self-efficacy links health literacy and numeracy to glycemic control. Journal of Health Communication, 15(S2), pp 146-158.

Park, S.Y., Kim, S.Y., Lee, H.M., Hur, K.Y., Kim, J.H., Lee, M.K., Sim, K.H. \& Jin, S.M. (2017). Diabetes camp as continuing education for diabetes self-management in middle-aged and elderly people with type 2 diabetes mellitus. Diabetes \& metabolism Journal, 41(2), pp 99-112. 
Polit, D.F. \& Beck, C.T. (2008). Nursing Research: Generating and Assessing Evidence for Nursing Practice. USA: Lippincott Williams \& Wilkins.

Semiz, S., Bilgin, Ü.Ö., Bundak, R. \& Bircan, I. (2000). Summer camps for diabetic children: an experience in Antalya, Turkey. Acta Diabetologica, 37(4), pp 197-200.

Winsett, R.P., Stender, S.R., Gower, G. \& Burghen, G.A. (2010). Adolescent self-efficacy and resilience in participants attending a diabetes camp. Pediatric Nursing, 36(6), p 293. 